\title{
Silencing the School Bell?
}

Reflecting on One School's Transformational Journey

\section{Cathy Lewin and Yvette Solomon}

\begin{abstract}
In this paper we explore one school's reinvention of itself as ensuring that every student could take full control of his or her learning. Located in a predominantly working-class area, the school has moved to a thematic curriculum, strong reliance on technology, major spatial change towards 'mini schools', and student self-management of learning. Drawing on Bourdieusian concepts, we examine through interviews with students and staff how much these changes have contributed to underlying transformational change in the educational habitus of the school's members. We analyse the discourses drawn on by the various players in terms of their changing roles within redrawn teacher-student relationships and new positionings with respect to student autonomy and self-management of learning. Taking into account the external constraints of national testing, accountability, and school competition, we found examples of students' recognition and critique of residual power structures in their lives and misrecognition of the nature of these underlying structural forces by staff.
\end{abstract}

Keywords: educational change, secondary education, habitus

\section{Introduction}

This paper focuses on one secondary school in England in which radical curriculum and organisational changes were introduced, beginning with an initial cohort of 11- to 12-year-olds (Year 7 in the English system) in 2008-2009, when we first visited the school. The intention was to provide students with personalised learning enhanced through the development of self-management skills within a technologyrich environment. Together with a redesign of the learning space as one large room for the year group with break-out areas, the delivery of the curriculum was transformed. Instead of all pupils following a set programme of subjects, moving from room to room, they chose which tutorials to attend (in the breakout areas) and when to study each subject within a flexible structure which was organised in terms of 
cross-curricular themes. In subsequent years, including 2010-2011, in which the data on which this paper is based were collected, further cohorts were recruited, and the personalised learning and tracking systems and buildings and curriculum design progressed further in the direction of the school's new vision, including the development of mixed-age vertically integrated 'families' in which students worked together across Years 7 to $9 .^{1}$

Our aim in researching the school in 2008-2009 was to carry out an evaluation to identify the achievements of the project, investigate the processes which brought about success, and highlight issues for the future. We visited again two years later to explore how the school had sustained radical change and its impact on the student community, given its location in a predominantly working-class area with high levels of unemployment, educational underachievement, and disaffection from schooling. The original evaluation was commissioned by the Local Authority (school district); initial findings with respect to implementation were very positive. Our subsequent engagement with the school was prompted by our interest in the longer-term development of the program and was not directly funded by the Local Authority. We had high hopes for the school in terms of its potential to make a difference and to make education relevant and accessible.

In this paper we recount how we adjusted our initial assumptions about the possibility for reinvention of schooling in the current climate, based on our realisation of the extent of the work that staff and students needed to do to enact the discourse of personalised learning against the backdrop of the education marketplace. We argue that this work can be understood in terms of misrecognition as defined by Nice (1977), that is, as part of a shared misconstrual of 'the true relations between the structure of [the] field and the structures of economic and political power' (p. xxiv). What is crucial about misrecognition is its effect on those power relations which 'are perceived not for what they objectively are but in a form which renders them legitimate in the eyes of the beholder' (Bourdieu \& Passeron, 1977, p. xxii). This process is particularly powerful in the field of schooling, where it enables reproduction of educational habitus. As Bourdieu and Passeron (1977) note,

legitimation of the established order by the School presupposes social recognition of the legitimacy of the School, a recognition resting in turn on misrecognition of the delegation of authority which establishes that legitimacy or, more precisely, on misrecognition of the social conditions of a harmony between structures and habitus sufficiently perfect to engender misrecognition 
of the habitus as a product reproducing what produces it and correlative recognition of the structure of the order thus produced. (p. 206)

We will suggest that the symbolic violence described by Bourdieu and Passeron in terms of the imposition of meanings which are in fact arbitrary is at work in the misrecognition of educational hierarchies and processes of surveillance as necessary for learning. Despite the school's attempt to disrupt traditions in its embracing of the discourse of personalised learning, whatever change is achieved in the institutional habitus is undermined by an educational habitus which is based on embedded power relations within the structure of the wider education field and the forces of social reproduction in the education marketplace. As Bourdieu (1990) notes, habitus bears a complex relationship to agency - 'even when they look like the realization of explicit ends, the strategies produced by the habitus and enabling agents to cope with unforeseen and constantly changing situations are only apparently determined by the future' (p. 61). Habitus reproduces itself, ensuring its own constancy and defending against change. Whilst change is possible, through reflexivity and an 'awakening of consciousness' (Bourdieu, 1977, p. 83) which comes about when the fit between habitus and field fails, we are less certain than we were that the school has effected fundamental change in terms of power relations, although, as we shall suggest, there may be some sense on the part of the students of the critique which brings the undiscussed into discussion... [when] the question of the natural or conventional character... of social facts can be raised' (Bourdieu, 1977, pp. 168-169).

\section{Reinventing the School: Every Student in Control of Their Own Learning}

\section{The Policy Context: The Discourse of Personalised Learning}

The concept of personalised learning has been explored in research contexts for some years (Fielding, 2001; Rudduck, 2002; Rudduck \& Flutter, 2000) but came to the fore of the policy agenda in the UK when noted by Prime Minister Tony Blair at the Labour Party Conference in 2003 and presented to head teachers later that year by David Miliband, the then schools standards minister. The ideas were refined and entered into educational policy in England from 2004 with the goal of raising achievement through individual responsibility: 'Personalised learning is the way in which our best schools tailor education to ensure that every pupil achieves the highest standard possible' (Miliband, 2006, p. 24). The discourse of personalisation 
emphasised 'the expectation of participation, fulfilment and success' (Department for Children, Schools and Families, 2008a, p. 7) which relied on learner investment in setting and reaching targets within a neoliberal framework of choice: 'Learners should be actively, continually engaged in setting their own targets, devising their own learning plans and goals, choosing from among a range of different ways to learn' (Leadbeater, 2006, p. 111).

Personalisation was one of New Labour's educational reforms designed to address social inequality through engaging disadvantaged learners by tailoring learning to meet students' needs and interests, thus raising academic achievement and improving social mobility (Harris \& Ranson, 2005; Thrupp \& Tomlinson, 2005). Educational success would, it was thought, overcome social disadvantage. At school organisation level, Miliband (2006) identified five components of personalised learning: using assessment for learning (ensuring children understand how they are doing and how they can improve), providing teaching and learning strategies that build on individual needs, enhancing curriculum choice, facilitating a radical approach to school organisation, and greater involvement of the wider community. Practical guidance for teachers in England extended these themes to define 'a pedagogy of personalised learning': high-quality teaching and learning, target setting and tracking, focussed assessment, intervention, pupil grouping, the learning environment, curriculum organisation, the extended curriculum, and supporting children's wider needs (Department for Children, Schools and Families, 2008a, p. 7).

The policy focus on personalisation prompted change in the centralised curriculum, and the revised national curriculum for Key Stage 3 (for pupils aged 11-14) introduced in 2007 underlined 'the flexibility to personalise learning and design a curriculum that meets the needs of their learners' (Qualifications and Curriculum Authority, 2007, p. 3) with 'less prescribed subject content' (p. 4). Embedded in the new curriculum was a framework of personal learning and thinking skills for learners (independent enquirers, creative thinkers, team workers, self-managers, effective participators, and reflective learners). Statutory tests at the end of Key Stage 3 (age 14) were abolished, and a greater emphasis placed on systematising teacher assessment (Qualifications and Curriculum Authority, 2008) and promoting assessment for learning (Department for Children, Schools and Families, 2008b; Torrance, 2009). Information and communications technology (ICT) was seen as a central means for enabling teachers to facilitate personalisation of learning and giving students more choices and flexibility (Järvelä, 2006; Robinson, Sebba, Mackrill, \& Higgins, 2008; Underwood et al., 2007). 


\section{The School Context: Silencing the School Bell}

The school is in an industrial town in the North East of England, with higher than average unemployment; the proportions of students at the school known to be eligible for free school meals and of students with a statement of special educational needs are also above average. A temporary two-storey building, designed to offer new kinds of learning spaces, was erected in the summer of 2008, ready for a new intake of pupils in September. A 12.9 million pound revamp of the whole school was completed by September 2011. During 2008 to 2009, the school was the subject of the external evaluation funded by the Local Authority which was discussed earlier. This was undertaken against the backdrop of the personalisation agenda and the promise of a 'fix' for social problems provided by the Building Schools for the Future capital investment programme (Leahy et al., 2009) with its promise of benefits accruing from the integration of ICT into schooling and the impact of new uses of space (Department for Education and Skills, 2006).

Inspired by a series of publications by David Hargreaves (2004-2007) on personalising learning produced for the Specialist Schools and Academies Trust, ${ }^{2}$ the school aimed for an education where there is 'blurring [of] both institutional and professional boundaries' (Hargreaves, 2004, p. 79) in which 'learning is for and by every member of the community, [and] its structure and culture will be different, reflecting new kinds of relationship among teachers, between teachers and students, and among students, especially mentoring' (p. 88). It aimed to make students more responsible for their learning by developing self-management and self-organisation skills. At the heart of this were a small-group, teacher-led tutorial system; learner devised learning plans (referred to as the 'learning journey'); a laptop/netbook for each student; a learning platform; and an open-plan learning space. Students were initially organised into family groups of about 15 and had tables in a particular area of the learning space so they could remain together, although they could also sit where they chose to, including vacant break-out areas if they wished. 'Family tutors' spent one hour a week with the family group covering pastoral issues. By the time of our second series of visits in 2010-2011, three mini-schools (smaller units within the main school with defined geographical space and a core team of staff) had been established, each with approximately 120 students from years 7, 8, and 9. Family tutor groups were mixed-age and had around 20-25 students.

In the first year, students chose a specified number of compulsory 15-minute tutorials offered in all subjects (run more than once to provide some degree of flexibility). Once the tutorials and external sessions had been selected, students 
completed the remainder of their timetable. They were required to meet the weekly time requirements for each subject (for example, three hours for mathematics) and planned their 'learning journey' accordingly. In effect, the 'learning journey' comprised a timetable for the week, divided into five hourlong slots each day (although there were no bells and limited requirements for movement to other areas of the school). As the innovation progressed, students were given more flexibility in relation to the amount of time spent on each subject, although they were still provided with guidance.

As the new curriculum was designed to be ICT-led, the teachers were encouraged to create resources which could be hosted on the school learning platform. These were used both in the tutorials and to provide follow-up material for students to work on independently; assessment tasks were also uploaded, enabling students some control over when they would complete the tasks. Our evaluation of the first year (2008-2009) suggested that there was a strong sense of purpose in the school, that the efficiency savings in terms of space and time were substantial, and that the school was developing a responsive and sophisticated assessment system. There were a great many positives: The new system did appear to have 'silenced the school bell'.

\section{Removing Our Rose-tinted Glasses}

Excited by the new approach to curriculum, use of space, and student autonomy, when we revisited the school in 2011 we carried positive assumptions about the way in which it repositioned learners and teachers, disrupting entrenched educational relationships and power structures. The school's difference, the promise of a more accessible education system, and the enthusiasm of the teachers were seductive. Expecting to find support for our assumptions, we conducted interviews with six members of the teaching staff and one para-professional and also held two focus groups, one with a group of Year 7 and 8 students, the other with a group of Year 9 students. In what follows, we recount our emerging recognition that all was not as it seemed.

\section{The Policy Context Again: 'Assessment for Learning',} Competition and Performativity

A major feature of the implementation of personalised learning in the school was the assessment system, involving computer-supported tracking and targeting which had become highly sophisticated by the time of our visit in 2011. For some subjects, 
notably mathematics, students were required to select the appropriate tutorial from three possibilities (based on the levels/sublevels of the English national curriculum), and levels were part of their daily discourse. Following the introduction of the assessment for learning strategy (Department for Children, Schools and Families, 2008b; Qualifications and Curriculum Authority, 2008) advocating a structured formative assessment approach, overall progress against National Curriculum levels and associated assessment criteria was constantly monitored, and data were entered on a highly detailed and sophisticated database which allowed teachers to see at a glance whether students were 'on track'.

Students were provided with 'passports' - a single document covering all subject areas, specifying the National Curriculum levels/sublevels, a number of assessment focus areas within each sublevel, and associated assessment criteria. Students provided evidence that their work met criteria and presented it to their teacher. If accepted, the 'passport' was 'stamped'. The passport was described by staff to be 'a dialogue between student and teacher' (Assistant Head Teacher), intended to convey a sense of shared ownership and student autonomy. As well as providing a record of achievement to date, it also acted as a guide for the student regarding which level/ sublevel they needed to cover next for each assessment focus area. For example, the passport could be used to decide which tutorial to sign up for next. Once sufficient evidence was provided, the teacher recorded the student's achievement(s) in the online system. Based on the student's expected rate of progress, every three weeks a colour-coded outcome for each subject was generated: for being on target, for being near the target, and for being under target. Family tutors and subject specialists, together with senior managers, were then able to analyse the achievement data for a variety of purposes, for example, to identify students who required additional help or to identify an assessment focus area which the majority of the cohort were struggling with. The deputy head, who had devised the monitoring software, emphasised the importance of learner awareness, but this was closely intertwined with staff monitoring and action in his use of a pilot metaphor:

Use a principle of a pilot who's guiding a plane, at the start of a flight, before they take off, they know where they're going and they're know where they're starting from. Well our model, if you like, in learning, is that students and staff should be fully aware of that as well. You know where a student starts, you know where they should be going. ... along the way there's going to be things that change, that mean you need to take adjustments, the only way the pilot takes those adjustments is by taking readings along the way to make sure he's 
still on track, well we need to do the same with the students and the students need to do the same so that we can make the adjustments change course as conditions dictate.

Whilst the deputy head uses the personalisation discourse of student ownership in the 'learning journey', he also talks quite clearly about controlling what they do, through creating 'drive':

And so that kind of gives the students some ownership of what they're going to do and actually allows us to generate registers to allow us to know that students are accessing the areas of the curriculum that are important to them. The second part of that, and the underpinning part of it if you like, is the assessment and intervention that we wanted to have in place. Real big believers that this is the single biggest driver behind what we are doing and it's the one thing that actually allows us to (a) know the students have made... are doing what they should be doing but (b) gives the students the drive to know that they're doing what they should be doing.

You can see how student 'ownership' is blended with the discourse of levels in the deputy head's discussion of the stamping process:

So the student says 'Mr [X] I've done this piece of work in science, I think therefore then I've achieved Level 5 in this certain focus area'. They then bring that, I then say 'well, in communication okay, I completely agree with you there', stamp. Once the stamps are built up there I then say 'okay, I'm confident now that you're showing me that area', so first stamp means you've given me some evidence, second stamp means confident now that you've shown me that you can do that. I would go to the online system then and add that onto there so as a teacher that's there, it's their electronic mark book if you like.

The deputy head said the surveillance provided by the system also facilitates instant communication with parents:

So that generates that code for us and then that generates a report that goes out to parents. So every three weeks these reports are printed out and sent home to parents, parents can then identify the progress that's being made within the different subject areas.

Arguing that the system enables more individualised learning in comparison with other schools, the deputy head underlines the fact that the school is in competition in the education marketplace and conflates further the roles of teacher and student in 
terms of who is monitoring learning. The pilot has to be prevented from going off course:

And obviously again, in many schools it becomes too late before you identify those students, so our system allows us to then alter the trajectory of the flight path to allow us to identify as soon as they fall off, and hopefully prevents coasting. (Deputy head)

Behind the personalised learning agenda is, of course, the original desire to raise achievement, and this school is no exception. Despite its liberal exterior, it is driven by the demands of performativity in the market (Ball, 2008; Torrance, 2009) and in particular by the students' anticipated grades in their future General Certificate of Secondary Education (GCSE) public examinations at age 16. Ultimately, this is an aspiring school, in all senses of the word - it aims to compete in the local education market. Indeed, since our last visit, the school has gained 'Academy' status (similar to 'Charter School' status), giving the school control of its budget, staff pay and conditions, its curriculum, and the length of terms/the school day. Arguably, this has put the school on a level playing field with another local school which already had Academy status and therefore increased the degree of competition. The impact of school choice policies on school funding in England means that attracting the few middle-class parents in the area is essential (see Reay, Crozier, \& James, 2011). So, ultimately, this is not just about a vision of a different way of schooling, it is about winning in the competition for funding. In what follows, we explore the implications of this, first for the teachers, and secondly for the students.

\section{The Discourse of Personalisation: Teachers' Stories}

The enthusiasm of school staff for the transformation of their school centred on the personalisation discourse in relation to their students' experiences and also their own changing roles and identities. The teachers we interviewed referred to student flexibility, choice, and ownership, perceived to enable greater freedom within the field. For example, the seating plans (devised by teachers to ensure that students were in groups that worked together best) for the 'floor' - the large open space which all mini-school families shared - were described as

[not] rigid for the whole week... so they'll leave and go out to a practical session, tables will be left free so students will join together to do project work and move around the room quite... quite a lot more now than they used to actually. (Lead teacher of learning) 
Students' self-regulation and self-management of learning were presented as being at the heart of this innovation designed to disrupt the institutional habitus. The key differences associated with this shift articulated by teachers were: more choices for learners in terms of planning and owning their learning journey and progressing at a suitable pace (facilitated through greater differentiation); a thematic crosscurricular approach enabling connections to be made between subjects and bringing the relevance of subject areas into focus; greater flexibility at Key Stage 4 (in terms of GCSE subject choices $^{3}$ ); and an increase in independent and peer learning.

I love the [school's innovation], it's something I like. It gives the kids responsibility, not like this in the classroom and what have you, but here, they're responsible for their own time, organisation, you know, everything. So that's what they need is to take their own responsibility rather than just relying on adult and teacher and mum and dad, what have you. (Mathematics teacher)

Originally, students had relatively strict guidance on the number of hours for each subject that they should allocate in their learning journey. However, by 2011 the deputy head teacher stated that students were given 'a guided amount of learning hours, a rough estimate' rather than 'hard and fast' requirements. He suggested 'we have as little input as we possibly can on those because it should be about students owning that'. This theme was echoed by others, too.

I'm just marking some history work and one of the students quite clearly had found it fascinating and had produced this huge long piece of work about castles and how castles had changed the middle ages and so on and had gone way above and beyond what the task was asking because they'd found it fascinating and they'd had the time to do it and they could create the time by managing their time elsewhere or spending time at home in a way that a traditional system just wouldn't allow you to do it. (Assistant head teacher)

Teachers also felt that silencing the school bell had increased their flexibility and radically changed their day-to-day experience; indeed, this did appear to have disrupted the educational habitus of the schools' members. Each day was seen as different, and teachers could manage their time and workload more easily. For example, they were able to assess students' work more regularly and discuss their feedback rather than provide short written feedback every three weeks as they had done previously. In addition, they could tailor their provision to meet the needs of their learners more easily. 
Where before I'll have some students that are sailing away with it and then I'll have some students that were quite struggling with it, I can now, rather than trying to accommodate that all within one class, in one hour, I can now ... then I'll now vary up my tutorials up, put an extra intervention one in there and now I can do another one to try and get students that are on merits that I have to do distinction work. So it's . . . and then I can change that week-to-week or day-byday. (Learning coach)

Another perceived difference for staff was the change in staff-student relationships. Teachers felt that students were more comfortable seeking help and guidance as required, either from themselves or their peers. In addition, because teachers based in mini-schools spent more time with each student than they would have done previously, they felt that they had better knowledge of the students' needs:

Having that little one-to-one time with them, that little 20 minutes, you'd never normally get that chance unless it had been after school or been at break time, all those time. (Learning coach)

I think one of the things that more traditional teachers may well have struggled with in terms of coming into this model is that blurring of that boundary in terms of who's the teacher, who's the learner. (Deputy head teacher)

There's a lot more of a relationship there with the students and they tend to be a little bit more forthcoming and they'll come and question you and you can ... and they're like they don't depend on you, but they just know that, you know, if they need to discuss something, they're not going to sit there, worrying about things, they do actually take action and try to speak to somebody about it straightaway. (Lead teacher of learning)

In terms of teachers' roles, the school shifted to a greater ratio of nonteachers to teachers and a distributed leadership model through the six mini-schools. In addition, new staff roles were introduced, such as the 'learning coach', responsible for developing students' independent learning skills (for example, self-management of learning) and also for supporting teachers to teach outside their subject specialism. Becoming a member of a cross-disciplinary team also contributed to a different experience. The shift from specialist to generalist was readily accepted by most of the teachers who found that the increased knowledge and sense of community rather than isolation was beneficial. 
We want to go down a route where we don't say this is your subject specialism anymore, I think the assessment might well hold us back slightly on that because of the importance of somebody saying I'm going to assess geography. That's the only thing there. But we'd love to ... generically advertise for teachers for children rather than teachers of science or whatever. (Deputy head teacher)

[The teachers] all kind of take ownership for everything, everybody kind of looks after everybody. (Learning coach)

However, our data were also speckled with discourses suggesting control underpinned by the monitoring and target-setting software, structures within the field of the school that were shaped by the policies of performativity which dominated the wider educational field. Teachers talked in depth about the assessment system and the need to ensure that students progressed through levels; when progress was seen to be insufficient, they talked of immediate and necessary 'interventions'.

If you're somebody who's brilliant at assessment focus 1, 2, 3, 4 but not 5 we can target that. We can see where that gap is and we can put in place the necessary intervention to make sure that gap is made up. (Assistant head teacher)

Thus it might be argued that the 19th century structure of classrooms, subjects, and timetables are being replaced by a 21st century structure of electronic monitoring and data tracking.

\section{Holding On to the Personalisation Discourse: Pupils' Stories}

We found that, on the whole, the students were also positive about the school's reinvention, recognising it as different to 'traditional' models and subscribing to the flexibility discourse, at least initially. Their comments complemented those of the teachers, suggesting that they experienced a new freedom of movement within the field, with increased autonomy and choice of what to do and when, within clearly acknowledged boundaries.

It's the fact of the freedom that you get, like you've got a laptop and you get to do your work whenever you want, like $[\mathrm{X}]$ said, then some of the work is quite free, so like you can do it by yourself or you can do it with someone else rather than having it set for you to do it then. And you've got to do it in this amount of time, when you can do it whenever you want or take it home and do it at home, you're quite free. (Y7/Y8) 
Well, in some ways it's easier because like ... in normal lessons you're just ... if you finish your work then you just have to stay in that lesson, but now we're doing this, if we finish a piece of work and we're like behind on another piece, we can just catch up with that, so in that way it makes it easier. (Y9)

The school also appeared to have achieved its goal of changing teacher-learner relationships, from their point of view, including that of making a space for peerto-peer teaching.

I think that's a good way of doing it because if you need help, rather than going to the teacher and asking, you can communicate with someone on your table to get help rather than like getting the teacher to help you. (Y7/Y8)

There's always teachers like walking around the room and like you can just put your hand up and they'll come and help you. (Y9)

Another positive involved autonomy in progress, but note here the discourse of levels and evaluation and a clear positioning of the teacher as legitimating authority, running counter to what has been said before.

And another thing good about this school is, you don't have to wait for the actual test to go up a level, you could be doing some working and because your work has been quite high for a couple of weeks, they'll say 'Right, you're doing really high work, I'm going to put you up a level' rather than having to wait for a test like three weeks. (Y7/Y8)

Whilst they attempt to adhere to the personalisation discourse, the discourse itself seems to rebound on the students, legitimising rules of the field which arguably work counter to the notion of student autonomy and choice. Responsibility for making progress was being devolved to students, but not the power to alter their overall direction of travel, that is to actually personalise their learning endeavours. The students reported control in the name of making sure that they would not forget their choices.

With my family group ... we have to stick our learning journeys on to the table so we don't forget about what tutorials we have and everything. (Y7/Y8)

In my family group ... we have a set learning journey that when . . . once we've finished it, we're not allowed to change it. (Y7/Y8)

And some students have no apparent choice at all.

The family group tutors just like put us in places. (Y7/Y8) 
And we was allowed to move around last year, weren't we, you could sit next to anyone but now it's like 'no'. (Y9)

Failure to meet their new responsibilities would result in a very traditional punishment of removing freedom.

If like you get... it's alright to have a deadline, but like if you don't get your work in by that deadline, it's like you get a lunchtime or an after-school detention . (Y7/Y8)

Indeed, the issue of self-organisation and 'autonomy' was experienced by some students as negative because it made them vulnerable to 'falling behind', an arguably contradictory concept in a learner-led system.

If I'm organising my own work, it feels like I fall behind and look like... I fall behind really easily. (Y9)

Similarly, the loss of conventional classroom activity increased the difficulties of selfmanagement.

It feels like you can get distracted really, easily, like if you like... somebody got into a conversation about a footballer, you could go on Wikipedia [on your laptop] to see how many goals a footballer scores, something like that. But like if you were in a normal classroom ... if the teacher was like showing you work, you couldn't exactly go up to the smartboard and do it. (Y9)

As we have seen, there were internal surveillance systems which legitimised the strategy of target setting and comparisons, but there were also powerful drivers outside the school in the wider field of educational competition which impacted on the students' experience of personalisation. In 2010 to 2011, in the third year of the innovation, the mini-schools became mixed age. The Year 9 students (age 14) in particular found this sudden shift unsettling. They felt that sharing the same learning space with the younger students was an issue; the divide between the two groups (structured by the curriculum with Year 7 and Year 8 comprising Key Stage 3 and Year 9 being the start of the students' journey towards final summative assessments in England the GCSE) was very apparent to them. The Year 9 students felt that the younger students benefitted but that they themselves were distracted and separated from some of their peers who had provided ready mutual support in the first two years. The pressure to succeed in their GCSEs (shaped by both the institutional habitus and their individual educational habitus) combined with their recognition of the risk involved in the school's reinvention. 
Last week, I was on a table with three Year 8 girls and a Year 7 girl on my own and like it was only last week I got moved, so there's a Year 9 boy on the table and a Year 8 girl and a Year 7 girl, but the Year 9 boy doesn't do the same like GCSE stuff as me. (Y9)

[The Y7s and Y8s] don't understand it's like your GCSEs and it's really important. (Y9)

Well like... we're the first year doing this so if like I know it sounds like weird, but like we're kind of the hamsters trying out the experiment like if this like could go wrong in the GCSE like the actual exams in like the main exams, because at the moment we haven't really got that much pressure in the exams because we're only Year 9. But next year will be like when like... gets up to the tests. (Y9)

It feels like we're under pressure because like apparently like each year everyone's got better grades. (Y9)

Every time you've gone to parents evenings, it's like 'We've improved $96 \%$ on GCSEs', it's like 'well, what happens if we let them down' in a way. (Y9)

The GCSEs also appeared to affect the teacher-pupil relationships, creating shifts in the rules of the game, which were unsettling but also seemingly obvious for the Year 9 students. Some teachers changed the way they related to the students (from less formal to more formal).

No, Miss $\mathrm{X}$ is more laid back, yeah, but it depends what subject or it's coming up to a GCSE as well then the teacher like changes the mood.

Like one... one day they can be proper happy but then it's GCSE the next day, it's like you can't ... you say 'Hi Miss' they don't ... it's just like they acknowledge and it's just not there, but funny in a way, but not really.

\section{Final Reflections: Misrecognition and Symbolic Violence}

The initial funded evaluation was a small-scale locally commissioned piece of work. The follow-up research we describe here took place in an ever more difficult economic climate in the UK without direct funding. Undertaken on a shoe-string budget, it was necessarily limited, and we recognize that we cannot make major claims on the basis of a small number of interviews in a single school. However, taking a Bourdieusian perspective in the analysis of our data has enabled us to trouble the positive 
assumptions embedded in the UK Government's educational policies. Teasing out the impact of a neoliberal focus on performativity in the enactment of personalised learning has revealed the contradictions between the ideal of learner autonomy and the reality of close surveillance and control, which is misrecognised as necessary to learning and consequently legitimated in the drive to achieve.

We still find the school's ambitions and continuing development to be exciting and stimulating. In our reflections on how we came to look at the innovation differently through our chosen theoretical framework, we are not trying to be overtly critical of the school, its staff, and its learners. Instead, what we are arguing is that what the school is trying to achieve is actually very difficult. The reproductive force of educational habitus means that reinvention cannot happen overnight or even over several years. Indeed, the senior managers of the school recognise that it is not perfect and are continuing to review and develop their ideas.

Whilst the personalisation agenda was intended to contribute to addressing social inequality (Harris \& Ranson, 2005), Thrupp and Tomlinson (2005) argue that the 'contradictions between a rhetoric of social justice and social inclusion, and the realities of divisiveness and injustice within a society pursuing market policies sustained by competition and "choice" reserved for privileged choosers, have become increasingly obvious' (p. 551). Our reflections on one school's transformational journey support this view. The marketisation forces at play in the wider educational field have prevented the new system under development in this school from establishing new structures and thus avoiding the reproduction of inequalities. The external driver of 'GCSE results' affects both staff and students. Personalisation may have potential to address social disadvantage but, we suggest, not whilst the exchange value of the GCSE remains in the outside world and schools are driven by the demands of performativity (Ball, 2008; Torrance, 2009).

The effect of these contradictions brings to light the role of misrecognition in our example. The teachers' and students' comments demonstrate a shared perception that the new local rules of the field, encapsulated in the silencing of the school bell, have facilitated greater freedoms and flexibility. However, whilst they subscribe to the discourse of freedom through personalised learning, there is a strong parallel discourse of the necessity of surveillance through the assessment system. In practice, the mechanisms of control place an emphasis on pace which works against the student control of learning, introducing an element of competition and, it seems, undermining assessment for learning as both staff and students focus on levels. Whilst they are committed to undoing power structures, teachers assert power in line with their pre-existing educational habitus, misrecognising this as for the benefit of students. 
Moreover, whilst the students misrecognise various arbitrary aspects of the system as demonstrating freedom (for example the need to seek approval from those in authority through the stamping of their passports), they also articulate contradictions in the system such as the dominating pressure to 'keep up' with the ideal target on their passport and to perform (in their GCSEs). They also note the impact on teacher-student relationships which are ostensibly more equal but which are always centred on evaluation - and sometimes overtly authoritative. Nevertheless, they do not express direct dissatisfaction with the level of control - their complaints focus on other students and are sometimes even directed towards their own inability to manage. As a result, the discourse of learner responsibility includes self-blame (see also Wilkins, 2012). An educational habitus which recognises teacher authority, assessment, and examination competition as legitimate prevails and perpetuates the symbolic violence of education noted by Bourdieu and Passeron (1977), despite local changes in the field.

\section{Notes}

1. The secondary school curriculum in England for young people aged 11-16 years is defined in two stages: Key Stage 3 for young people aged 11-13 years (Year 7 and Year 8) and Key Stage 4 for young people aged 14-16 years (Year 9 to Year 11). The school in this study adopted this approach. Some schools in England deliver Key Stage 3 over three years (Year 7 to Year 9) and Key Stage 4 over two years (Year 10 and Year 11).

2. The Specialist Schools and Academies Trust is a nonprofit organisation providing continuing professional development and support for schools in England and internationally, with a particular focus on the use of ICT and an overall aim of raising achievement.

3. Under the previous system, GCSE subject choices were constrained by timetable restrictions such that students were asked to select a subject from each of a number of option boxes. At this school, students were at liberty to choose any subject from those offered at the school.

\section{References}

Ball, S. J. (2008). The education debate. Bristol: The Policy Press.

Bourdieu, P. (1977). Outline of a theory of practice. Cambridge: Cambridge University Press. Bourdieu, P. (1990). The logic of practice. Cambridge: Polity Press.

Bourdieu, P., \& Passeron, J.-C. (1977). Reproduction in education, society and culture (2nd ed., R. Nice, Trans.). London: Sage.

Department for Children, Schools and Families. (2008a). Personalised learning: A practical guide (DCSF-00844-2008). Retrieved at http://webarchive.nationalarchives.gov.uk/ 20130401151715/https://www.education.gov.uk/publications/eOrderingDownload/ 00844-2008DOM-EN.pdf 
Department for Children, Schools and Families. (2008b). The assessment for learning strategy (DCSF-00341-2008). Retrieved at http://webarchive.nationalarchives.gov.uk/ 20130401151715/https://www.education.gov.uk/publications/eOrderingDownload/ DCSF-00341-2008.pdf

Department for Education and Skills. (2006). 2020 vision: Report of the teaching and learning by 2020 review group (04255-2006DOM-EN).

Fielding, M. (2001). Students as radical agents of change. Journal of Educational Change, 2, 123-141. doi:10.1023/A:1017949213447

Hargreaves, D. (2004). Learning for life: The foundations for lifelong learning. Bristol: Policy Press.

Harris, A., \& Ranson, S. (2005). The contradictions of education policy: Disadvantage and achievement. British Educational Research Journal, 31, 571-587. doi:10.1080/ 01411920500240726

Järvelä, S. (2006). Personalised learning? New insights into fostering learning capacity. In Personalising education (pp. 31-46). Paris: Organisation for Economic Co-operation and Development.

Leadbeater, C. (2006). The future of public services: Personalised learning. In Personalising education (pp. 101-114). Paris: Organisation for Economic Co-operation and Development.

Leahy, P., Anderson, J., Chim, E., Glover, J., MacLeod, S., McCarthy, V., ... Reddaway, J. (2009, February). The building schools for the future programme: Renewing the secondary school estate. London: National Audit Office. Retrieved from http://www.nao.org.uk/wp-content/uploads/2009/02/0809135.pdf

Miliband, D. (2006). Choice and voice in personalised learning. In Personalising education (pp. 21-30). Paris: Organisation for Economic Co-operation and Development.

Nice, R. (1977). Translator's note. In P. Bourdieu \& J.-C. Passeron (1977), Reproduction in education, society and culture (2nd ed., R. Nice, Trans., pp. xxiii-xxvi). London: Sage.

Qualifications and Curriculum Authority. (2007). The new secondary curriculum: What has changed and why? London: Author. Retrieved from http://dera.ioe.ac.uk/6564/1/qca-073172-new_sec_curric_changes.pdf

Qualifications and Curriculum Authority. (2008). Assessing pupils' progress: Assessment at the heart of learning. London: Author. Retrieved from https://orderline.education.gov.uk/ gempdf/184721746X.PDF

Reay, D., Crozier, G., \& James, D. (2011). White middle-class identities and urban schooling. Basingstoke: Palgrave Macmillan.

Robinson, C., Sebba, J., Mackrill, D., \& Higgins, S. (2008, April). Personalising learning: The learner perspective and their influence on demand. Coventry: British Educational Communications and Technology Agency.

Rudduck, J. (2002). The transformative potential of consulting young people about teaching, learning and schooling. Scottish Educational Review, 34, 123-137.

Rudduck J., \& Flutter, J. (2000). Pupil participation and pupil perspective: 'Carving a new order of experience'. Cambridge Journal of Education, 30, 75-89. doi:10.1080/ 03057640050005780

Thrupp, M., \& Tomlinson, S. (2005). Introduction: Education policy, social justice and 'complex hope'. British Educational Research Journal, 31, 549-556. doi:10.1080/ 01411920500240684 
Torrance, H. (2009). Pursuing the wrong indicators? The development and impact of testbased accountability. In K. E. Ryan \& J. B. Cousins (Eds), The Sage international handbook of educational evaluation (pp. 483-498). London: Sage.

Underwood, J., Baguley, T., Banyard, P., Coyne, E., Flint, L. F., \& Selwood, I. (2007, July). Impact 2007: Personalising learning with ICT. Coventry: British Educational Communications and Technology Agency.

Wilkins, A. (2012). The spectre of neoliberalism: Pedagogy, gender and the construction of learner identities. Critical Studies in Education, 53, 197-210. doi:10.1080/17508487.2012. 672332

\section{About the Authors}

Cathy Lewin is professor of education in the Education and Social Research Institute, Manchester Metropolitan University. Her research interests concern the use of technology to support educational change in schooling and young people's use of technology in formal, nonformal and informal settings. She has more than 15 years' experience of evaluating technology use in schools for both the UK government and the European Commission.

Yvette Solomon is professor of education in the Education and Social Research Institute, Manchester Metropolitan University, and professor II in mathematics education in the Faculty of Education and International Studies, Oslo, and Akershus University College of Applied Sciences, Norway. Her main research focus is on the development of learners' relationships with mathematics from primary years through adulthood and their associated identities of inclusion and exclusion. 